\title{
PENERAPAN METODE HAVERSINE UNTUK PENCARIAN KULINER TERDEKAT DI KOTA PEKANBARU
}

\author{
Willyansah \\ AMIK TRI "DHARMA" PEKANBARU \\ Jalan Soekarno Hatta, No.99B, Labuh Baru, Payung Sekaki, Kota Pekanbaru', 28292 \\ e-mail : wilyerta@gmail.com
}

\begin{abstract}
ABSTRAK
Kemajuan teknologi yang semakin pesat sangat mempengaruhi manusia secara tidak langsung. Komputer sebagai salah satu hasil kemajuan teknologi dapat membantu manusia dalam meningkatkan kualitas dan kuantitas kerja seseorang. Kemajuan teknologi saat ini dapat membantu dalam pengolahan data, dimana pada kenyataan ini komputer sangat diperlukan, mengingat data yang dibutuhkan memerlukan format dan laporan yang baik dan tepat. Teknologi mobile merupakan teknologi mutakhir yang nantinya mampu mempermudah seseorang dalam mencari sesuatu secara instan sama seperti dalam melakukan pencarian toko kuliner dan oleh-oleh yang berada di kota pekanbaru. Dengan adanya aplikasi ini nantinya membantu kita dalam mencari tempat kuliner yang dekat dan mudah di jangkau.
\end{abstract}

Kata kunci : Kuliner, Haversine, Mobile

\section{ABSTRACT}

Technological advances that are increasingly rapidly affecting humans indirectly. Computers as one of the results of technological advances can help humans improve the quality and quantity of a person's work. Current technological advances can assist in data processing, where in fact computers are very much needed, considering that the required data requires good and precise formats and reports. Mobile technology is the latest technology that will be able to make it easier for someone to find something instantly, just like searching for culinary and souvenir shops in the city of Pekanbaru. With this application, it will help us in finding culinary places that are close and easy to reach.

Keywords : Culinary, Haversine, Mobile

\section{PENDAHULUAN}

Kota pekanbaru memiliki tujuan tempat wisata kuliner sebanyak 554 lokasi kuliner dan tempat penjualan oleh-oleh sebanyak 41 lokasi, (Kota pekanbaru memiliki tujuan tempat wisata kuliner sebanyak 554 lokasi kuliner dan tempat penjualan oleh-oleh sebanyak 41 lokasi (Dinas Pariwisata Kota Pekanbaru, 2020) saat ini sumber data informasi mengenai beberapa tempat wisata kuliner dan penjualan oleh-oleh yang berada di kota pekanbaru diambil dari dinas pariwisata dan kebudayaan di kota pekanbaru.

Adapun kendala yang dihadapi adalah kurangnya sarana untuk mendapatkan informasi mengenai lokasi tempat wisata kuliner dan tempat pencarian oleh-oleh yang berada di kota pekanbaru. Adanya sarana informasi mengenai lokasi-lokasi wisata kuliner yang berada di kota pekanbaru dapat memeberikan pengetahuan terhadap lokasi-lokasi wisata kuliner yang belum diketahui. Teknologi informasi saat ini telah menghadirkan kemudahan dalam pemberian informasi secara geografis, sehingga dapat mendukung pemberian informasi lokasi suatu tempat. Adanya sistem informasi geografis mengenai tempat-tempat wisata kuliner suatu daerah dapat mendukung kegiatan para wisatawan serta dapat meningkatkan minat wisatawan untuk berkunjung ke lokasi kuliner dan penjualan oleh-oleh tersebut.

Adapun identifikasi masalah dalam penelitian ini yaitu Kurangnya sarana informasi secara geografis mengenai wisata kuliner dan pembelian oleh-oleh yang berada di kota pekanbaru dan 


\section{INFORM T I K A}

Jurnal Informatika, Manajemen dan Komputer, Vol. 13, No. 2, Desember 2021

eISSN : 2580-3042

pISSN : 1979-0694

Kurangnya rekomendasi mengenai tempat-tempat wisata kuliner dan pembelian oleh-oleh yeng berada di kota pekanbaru serta sulitnya mengetahui jarak terdekat untuk menuju tempattempat wisata kuliner dan pembelian oleh-oleh di kota pekanbaru.

Adapun rumusan masalah yang di dapat adalah dalam penelitian ini adalah Bagaimana membangun sarana informasi secara geografis mengenai wisata kuliner yang nantinya juga dapat merekomendasikan mengenai tempattempat wisata kuliner dan oleh-oleh yang berada di kota pekanbaru

\section{METODOLOGI PENELITIAN}

Metode yang digunakan dalam penelitian ini adalah model waterfall. Metode waterfall adalah metode yang menyarankan sebuah metode yang bagaimana melihat suatu permasalahan secara sistematis dan terstruktur melalui tahapantahapan yang ada pada SDLC untuk membangun sebuah perangkat lunak. Menurut sukamto dan salahuddin (2013:26) mengemukakan bahwa SDLC atau Software Defelovement Life Cycle atau sering disebut juga System Develovment Cycle adalaha proses pengembangan atau mengubah suatu sistem perangkat lunak dengan menggunakan model-model dan metodologi yang digunakan untuk mengembangkan sistemsistem perangkat lunak sebelumnya,berdasarkan best parctice atau cara-cara yang sudah teruji baik. Berikut adalah gambar model waterfall secara umum :

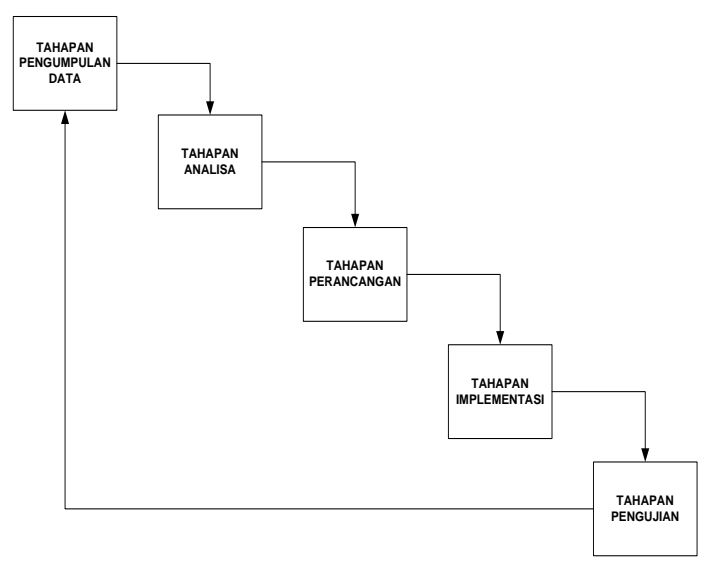

\section{Gambar 1 Model Waterfall}

Tahapan-tahapan dalam model waterfall

1.Tahapan Pengumpulan Data

Pengumpulan data adalah aktivitas mencari data yang dibutuhkan dalam rangka mencapai tujuan penelitian sosial. Data adalah bahan keterangan berupa himpunan fakta, angka, huruf, grafik, tabel, lambang, objek, kondisi, situasi. Data merupakan bahan baku informasi.

\section{Tahapan Analisa Data}

Pada tahapan analisa ini informasi yang diperoleh pada tahap pengumpulan data kemudian dianalisa untuk memenuhi kebutuhan dalam pembangunan sistem yang diusulkan. Analisa merupkan penguraian dan mengidenfikasi permasalahan yang ada sehingga dapat memberikan solusi

\section{Tahapan Perancangan}

Tahapan perancangan ini secara umum bertujuan memberikan gambaran dan acuan terhadap User untuk memudahkan perancangan. Menurut John dan Garry Grudnitski "Perancangan desain sistem didefinisikan sebagai gambaran dan pembuatan sketsa atau peraturan dari beberapa elemen yang terpisah ke dalam satu kesatuan yang utuh dan berfungsi”. Jadi dapat disimpulkan bahwa perancangan desain sistem adalah tahapan berupa penggambaran, perencanaan dan pembuatan dengan menyatukan beberapa elemen terpisah ke dalam satu kesatuan untuk memperjelas bentuk sebuah sistem. Pada tahapan perancangan ini yaitu menggunakan perancangan UML(Unified Modeling language ).

\section{Tahapan Implementasi}

Tahapan implementasi merupakan tahapan kegiatan menuliskan kode program dengan menggunakan bahasa pemrograman yang sudah ditentukan. Menurut (Prayogi, 2017) Implementasi sistem adalah suatu proses untuk menempatkan dan menerapkan informasi baru kedalam operasi. Dalam mengimplementasikan sistem maka dibutuhkan perangkat pendukung berupa perangkat keras dan perangkat lunak. Adapun bahasa pemrograman yang digunakan dalam pembangunan sistem ini adalah bahasa pemrograman Java, Android studio, MySQL sebagai Database serverdan tools PHPMyAdmin. Untuk tampilan halaman menggunakan HTML dan CSS. Google Maps API untuk menampilkan Peta. Algoritma yang digunakan dalam pembangunan sistem ini adalah Algoritma Haversine, cara kerja dari algoritma ini yaitu Algoritma Haversine graf berarah dan berbobot. Serta output dari algoritma Haversine adalah dengan menghitung bobot terkecil dari semua lintasan yang menghubungkan sebuah pasangan titik, dan melakukannya sekaligus untuk semua pasangan titik (Vera Apriliani Nawagusti, 2018). 
IN F ORM A I I A

Jurnal Informatika, Manajemen dan Komputer, Vol. 13, No. 2, Desember 2021

eISSN : 2580-3042

pISSN : 1979-0694

5.Tahapan Pengujian

Tahapan pengujian merupakan tahapan akhir dalam metode tugas akhir dimana tahapan ini lakukan untuk pengujian suatu sistem yang telah dibangun untuk memastikan suatu sistem bisa digunakan dan dijalankan dengan baik. Adapun metode pengujian sistem ini adalah pengujian secara black-box.

\section{HASIL DAN PEMBAHASAN}

\section{A. Metode Haversine}

(Wijaya, Indra, 2018) Haversine Formula ialah persamaan penting dalam sistem navigasi, nantinya formula haversine ini akan menghasilkan jarak terpendek antara dua titik, misalnya pada bola yang diambil dari garis bujur (longtitude) dan garis lintang (latitude).

Haversine formula merupakan penerapan dari konsep trigonometri yang merupakan bagian dari geometri. Rumus Haversine ialah persamaan yang penting dalam navigasi, yang menghasilkan jarak lingkaran besar antara dua titik (latitude dan longitude) pada permukaan bola (bumi) berdasarkan bujur dan lintang. Penggunaan rumus ini cukup akurat untuk sebagian besar Perhitungan, juga mengabaikan ketinggian bukit dan kedalaman lembah di permukaan bumi berikut ini bentuk Rumus Haversine

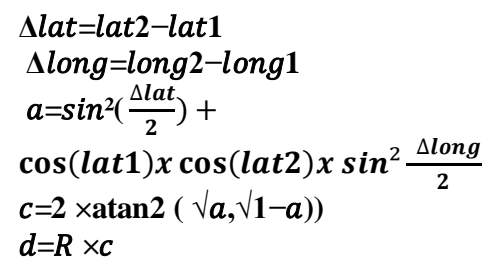

Keterangan :

$\mathbf{R}=$ jari-jari bumi sebesar $6371(\mathrm{~km})$

$\Delta$ lat $=$ besaran perubahan latitude

$\Delta$ long = besaran perubahan longitude

$\mathbf{c}=$ kalkulasi perpotongan sumbu

$\mathbf{d}=\operatorname{jarak}(\mathrm{km})$

\section{B. Rancangan Sistem}

\section{Use Case Diagram}

Use case diagram menggambarkan bagaimana proses-proses yang akan dilakukan oleh aktor terhadap sebuah sistem. Dalam hal ini yang bertindak sebagai aktor adalah admin, customer.
Pada use case diagram terdapat berbagai macam bagian, yaitu bagian aktor yang disimbolkan dalam bentuk orang, bagian use case disimbolkan dalam bentuk bulat serta hubungan antara aktor dan use case disimbolkan dengan tanda panah

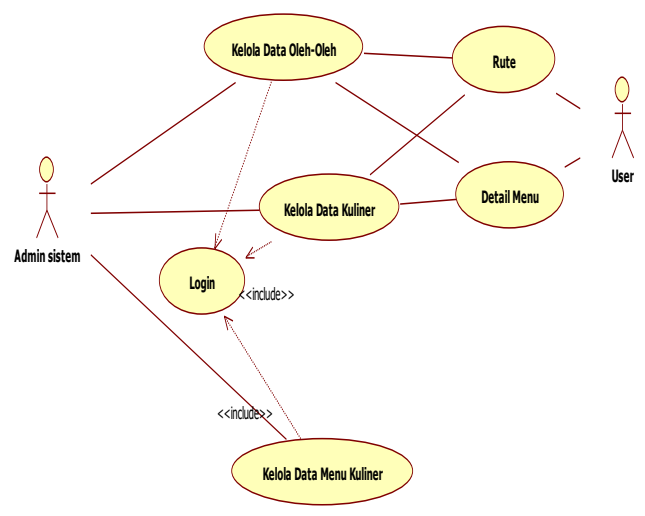

Gambar 2. Use Case Diagram

\section{Class Diagram}

Class diagram menggambarkan bagaimana struktur dari perancangan sistem. Semua proses yang dilakukan oleh aktor terhadap aplikasi akan didefinisikan dengan menggunakan class diagram. Class diagram menunjukkan bentuk visualisasi dalam pembuatan sistem. Masing-masing class memiliki attribute dan metoda agar sesuai dengan proses yang terjadi. Pada perancangan sistem ini, yang menjadi objek dalam pembuatan class diagram adalah tabel-tabel yang terdapat pada database sistem

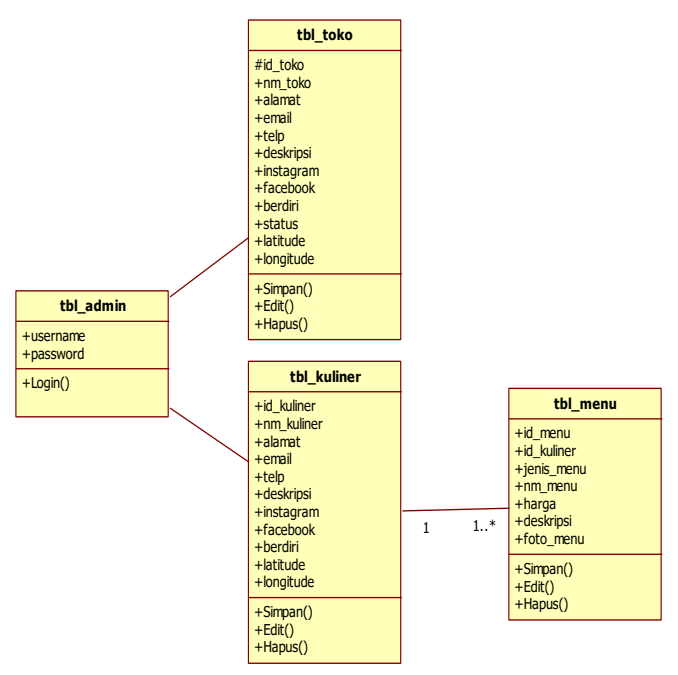

Gambar 3. Class Diagram 
I N F O R M A T I A

Jurnal Informatika, Manajemen dan Komputer, Vol. 13, No. 2, Desember 2021

eISSN : 2580-3042

pISSN : 1979-0694

\section{Activity Diagram}

Activity diagram menggambarkan bagaimana aktifitas yang terjadi dalam suatu sistem yang akan dirancang. Activity diagram sama seperti halnya flowchart yang menggambarkan proses yang terjadi antara aktor dan sistem.

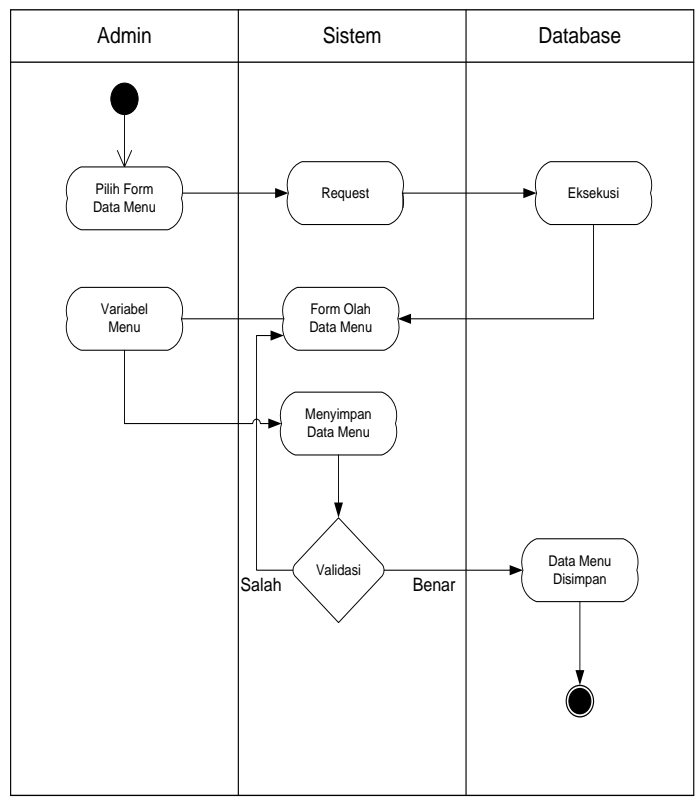

Gambar 4 Activity Diagram

\section{Tampilan Sistem}

Hasil dan pembahasan berisi tentang pembahasan serta hasil akhir atau output program atau analisa metode dari penelitian tersebut.

1. Tampilan Dashboard Awal Aplikasi

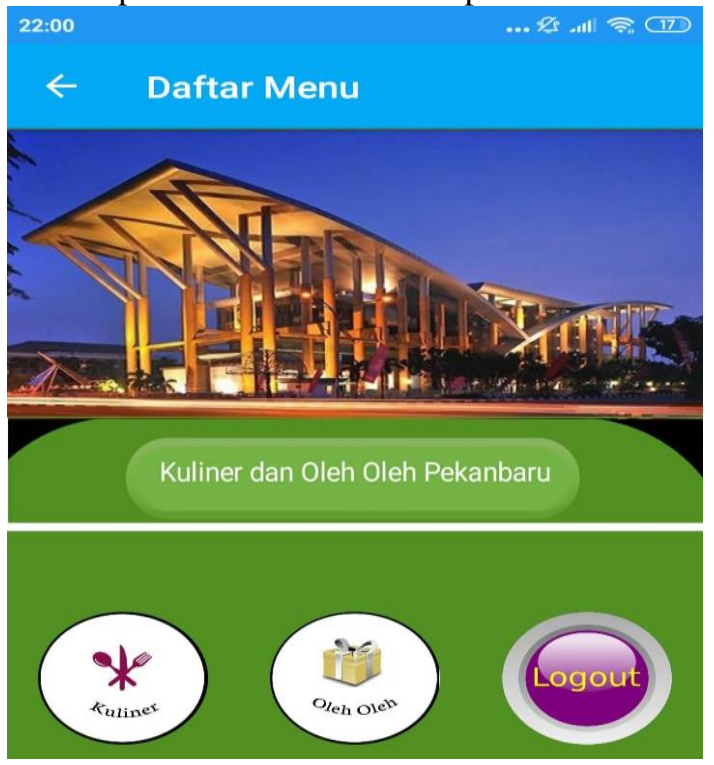

Gambar 5 Tampilan Menu
2. Tampilan List Data Kuliner
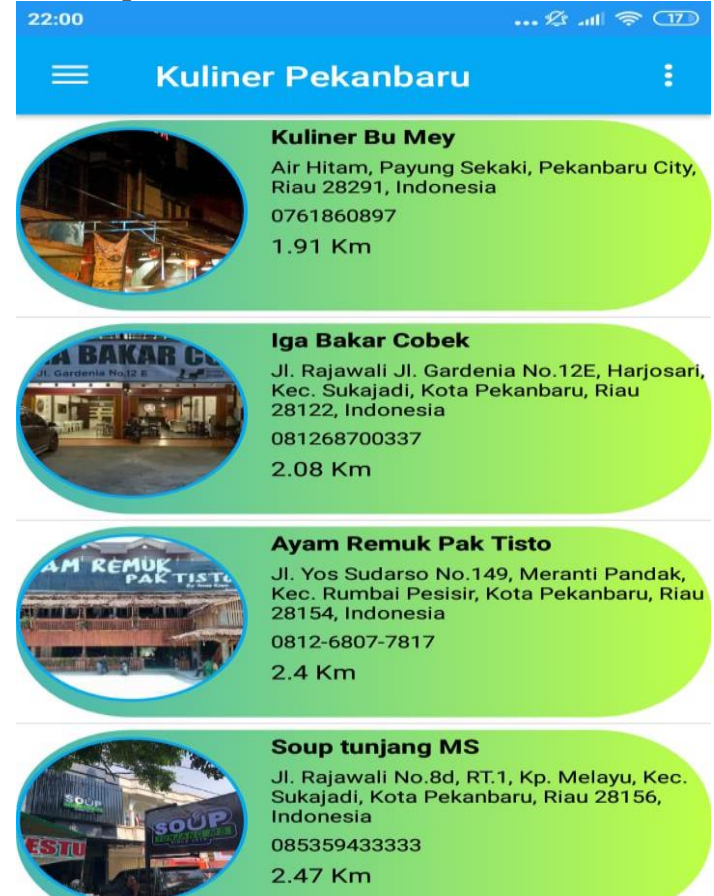

Gambar 6 Tampilan List Kuliner

3. Tampilan List Data Oleh-oleh

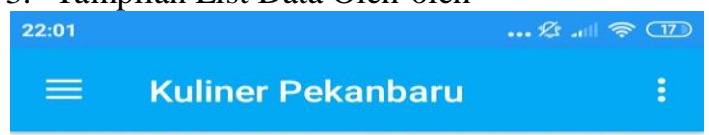

Vanhollano Bakery
JI. Durian No.16E, Labuh Baru Tim., Kec.
Payung Sekaki, Kota Pekanbaru, Riau
28156, Indonesia
$(0761) 7871436$
$2.32 \mathrm{Km}$
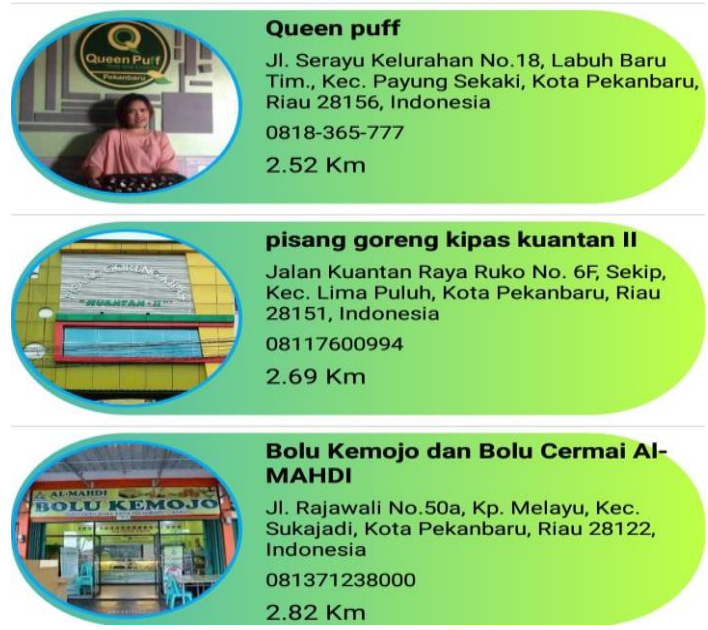

Gambar 7 Tampilan Data Oleh-Oleh 
INFORM T IKA

Jurnal Informatika, Manajemen dan Komputer, Vol. 13, No. 2, Desember 2021

eISSN : 2580-3042

pISSN : 1979-0694

4. Tampilan Detail

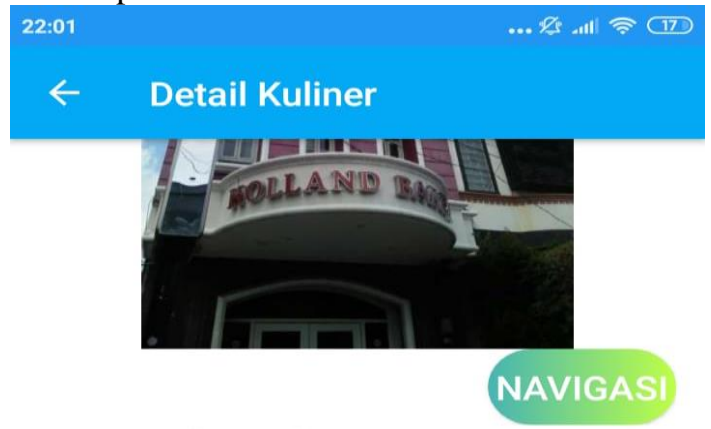

Nama Toko Kuliner

Jl. Durian No,16E, Labuh Baru Tim., Kec. Payung Sekaki, Kota Pekanbaru, Riau 28156, Indonesia (0761) 7871436

\section{Deskripsi Gambar}

NAMA PEMILIK : Erickson Marpaung

\section{Soal Media}

Vanhollano Bakery

Vanhollano Bakery

TAHUN BERDIRI 2009

Aktif

Gambar 8 Tampilan Detail Menu

5. Load data navigasi

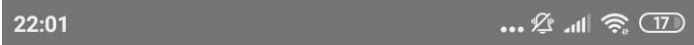

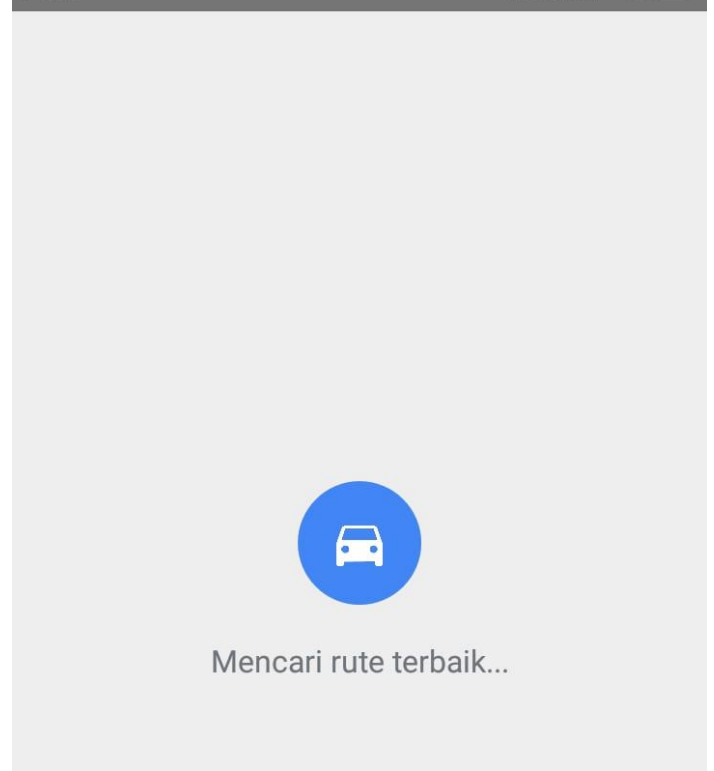

Gambar 9. Load Data Navigasi
6. Navigasi

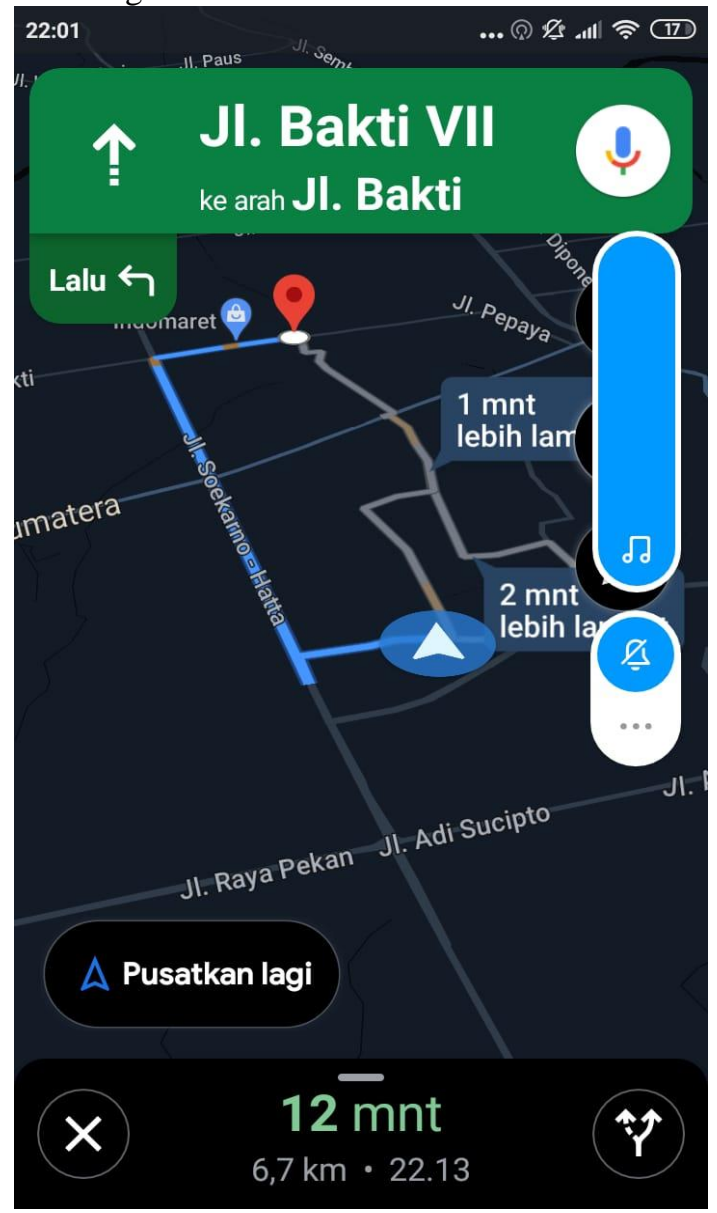

Gambar 10 Rute Navigasi

\section{KESIMPULAN}

Kesimpulan yang penulis dapatkan dalam penelitian ini antara lain :

1. Aplikasi ini akan memudahkan user dalam mencari tempat kuliner dan oleholeh yang ada di dalam kota pekanbaru.

2. Fitur detail tentang kuliner dan oleh-oleh akan lebih memudahkan user dalam memilih makanan yang akan di beli nantinya.

3. Pemanfaatan Database MySQL, akan lebih mudah mencari data lampau yang suatu saat di butuhkan.

\section{REFERENSI}

(Erik Kurniadi, 2018; Kridalaksana et al., 2018; Prayogi, 2017; Purnomo et al., n.d.; Tangalele et al., 2019; Vera Apriliani Nawagusti, 2018)Erik Kurniadi, H. B. (2018). Berbasis Android Menggunakan Metode Location Based Service ( Lbs ). Jurnal Cloud Information, 3, 28-35. 
INFORM T I I A

Jurnal Informatika, Manajemen dan Komputer, Vol. 13, No. 2, Desember 2021

elSSN : 2580-3042

pISSN : 1979-0694

https://journal.uniku.ac.id/index.php/cloudi nformation/article/view/1230/918

Kridalaksana, A. H., Studi, P., Komputer, I., Mulawarman, U., Panajam, J., Gunung, K., Universitas, K., Samarinda, M., Timur, K., J, M. R., \& Green, H. (2018). PENERAPAN FORMULA HAVERSINE PADA SISTEM INFORMASI. 13(1), 14-21

Prayogi, D. (2017). Pengembangan Potensi Wisata Kuliner Kota Malang Berbasis Sumber Daya Lokal. Jurnal Pariwisata Pesona, 2(1), 1-13. https://doi.org/10.26905/jpp.v2i1.1260

Purnomo, Y. A., Informasi, T., Informatika, T., Malang, P. N., Informasi, A., \& Berbasis, P. (n.d.). Rancang bangun aplikasi informasi pariwisata berbasis android dengan optimasi biaya. 1-5.

Tangalele, C. S., Rindengan, Y. D. Y., \& Sambul, A. M. (2019). Rancang Bangun Aplikasi Pariwisata di Kabupaten Parigi Moutong Berbasis Android. 14(2), 151158.

Vera Apriliani Nawagusti. (2018). Penerapan Algoritma Floyd Warshall Dalam Aplikasi Penentuan Rute Terpendek Mencari Lokasi BTS (Base Tower Station) Pada PT.GCI Palembang. Jurnal Nasional Teknologi Dan Sistem Informasi, 4(2), 81-88. https://doi.org/10.25077/teknosi.v4i2.2018. 81-88 